\title{
Література:
}

1. Цема Є.В. Порівняльна оцінка ефективності методів радикального хірургічного лікування гострої пілонідальної хвороби. Український журнал малоінвазивної та ендоскопічної хірургї. - 2013. - Т. 17, № 3. - C. 22-29.

2. Thompson M.R. Pilonidal sinus disease. Anorectal and colonic diseases. A practical guide to their management / M.R.Thompson, A.Senapati, R.B. Kitchen editors: Jean-Claude R. Givel, Neil Mortensen, Bruno Roche. 3rd ed. (Springer). - 2010. - P. 373-386.

3. Шавлюк Р.В., Конопліцький В.С., Паламарчук І.П. Модельне обгрунтування просторових параметрів хірургічного доступу при мініінвазивному оперативному лікуванні пілонідальної хвороби у дітей. Хірургія дитячого віку. - 2020. - Т. 66, № 1. С. 10-20.

DOI https://doi.org/10.30525/978-9934-588-81-5-1.54

\section{PROBLEM OF CHOICE: ELECTRONIC CIGARETTES IN THE MEDICAL ENVIRONMENT}

\author{
Yashkina T. O. \\ Assistant at the Department of Family Medicine \\ of the Faculty of Postgraduate Education \\ State Institution "Dnipropetrovsk Medical Academy \\ of the Ministry of Health of Ukraine" \\ Dnipro, Ukraine
}

Introduction. At the present stage of development of society, medical practice pays considerable attention to the impact of active and passive smoking on different groups of the population, adults $[2,4]$ and children [3]. Despite the programs to counter the spread of tobacco smoking (MPOWER), adopted in more than 150 countries around the world, the tobacco industry is successfully increasing the number of consumers [1]. The emergence and active spread of new forms of tobacco smoking is attracting an increasing number of people, especially among young people. Future medical workers are no exception.

Materials and methods. An anonymous survey was conducted using the questionnaire of the Global Adult Tobacco Survey (GATS) for Ukraine, modified and adapted by us in accordance with our goal.

The anonymous survey was attended by 171 people (medical students and interns) aged 18 to 30 years. 
Results. The average age of the respondents was 22 years (Me (25\%; $75 \%$ ) 19 ; 24), the gender ratio: men - 29\% (49 people), women $-71 \%$ (122 people).

$100 \%$ of the respondents have heard anything about E-cigarettes. It should be noted that for the position "source of information about electronic cigarettes", students note the following: "advertising" (media, Internet, advertising on the street, advertising in stores) $-68 \%$, "environment" (acquaintances, colleagues at work or school, friends, relatives) $-46 \%$. They tried to use $-48.36 \%$ (95\% CI 39.49-57.23).

Evaluation of the survey results for the position "Opinion about the reason for using E-cigarettes" showed the following (multiple opinion option): "necessity" - 1.64\%; «Habit» - 52.46\%; «Dependence» - 32.79\%; "Disease" - 4.1\%; "Social status support" - 9.01\%; «Fashion»-53.28\%; $4.92 \%$ of the respondents gave their own version. When studying the category «your own option», one can single out reasons such as «variety of tastes», «less odor», «indoor use», «curiosity».

Conclusions. Despite the fact that the majority of respondents have knowledge about the dangers of any kind of smoking, every fifth student of a medical university is an active consumer of E-cigarettes. The poll points to the social reasons for trying E-cigarettes - fashion and support for social status. Unfortunately, more than two-thirds of future physicians become hostages of an advertising campaign, as well as the lack of a solid evidence base about the risks of using alternative types of tobacco smoking.

\section{References:}

1. Глобальне опитування дорослих щодо вживання тютюну (Global Adult Tobacco Survey - GATS) (укр. мова). - Київ, 2017. - 240 с.

2. Kvasha E.A., Sribnaya O.V. Электронные системы доставки никотина - технологическое решение проблемы курения или новая угроза здоровью? / Е. А. Кваша, О. В. Срибная // Український кардіологічний журнал. - 2017. - № 3. - С. 79-85.

3. Bashkirova N. S., Vysochina I. L. Sensitivity of bronchial receptors under the effect of tobacco smoke in the conditions of various activity of the thyroid gland in children. Медичні перспективи. 2019. Т. 24, No 3. C. 53-57.

4. Vytryhovskiy A. I., Fedorov S. V., Kylaec N. М. Ризик появи життєво небезпечних аритмій у пацієнтів, які палять тютюн Запорізький медичний журнал.- 2017.- Т. 19, № 3(102). - С. 276-281. 